\title{
Where is the common ground between bone marrow mesenchymal stem/stromal cells from different donors and species?
}

\author{
Elena Jones ${ }^{1 *}$ and Richard Schäfer ${ }^{2}$
}

\begin{abstract}
Mesenchymal stem/stromal cells (MSCs) feature promising potential for cellular therapies, yet significant progress in development of MSC therapeutics and assays is hampered because of remarkable MSC heterogeneity in vivo and in vitro. This heterogeneity poses challenges for standardization of MSC characterization and potency assays as well as for MSC study comparability and manufacturing. This review discusses promising marker combinations for prospective MSC subpopulation enrichment and expansion, and reflects MSC phenotype changes due to environment and age. In order to address animal modelling in MSC biology, comparison of mouse and human MSC markers highlights current common ground of MSCs between species.
\end{abstract}

\section{Introduction}

In contrast to hematopoietic stem cells (HSCs), progress in the field of mesenchymal stem/stromal cells (MSCs) has been impeded by inconsistency in terminology and the lack of suitable assays to test the self-renewal of cells in vivo [1]. Furthermore, academic and industrial efforts in the development of cell therapies with cultureexpanded MSCs tend to surpass our basic-science understanding of the physiological roles of these cells in vivo [1-3]. It is fair to say that nearly 15 years since a seminal letter by Stanton Gerson, MSCs remain to some degree 'second class marrow citizens' [4] in comparison with much better defined HSCs-which at first sight might appear surprising because advanced, and still improving, detection and characterization technologies have been

\footnotetext{
* Correspondence: msjej@leeds.ac.uk

'Leeds Institute of Rheumatic and Musculoskeletal Medicine, Leeds University, Room 5.24 Clinical Sciences Building, St James's University Hospital, Leeds LS9 7TF, UK

Full list of author information is available at the end of the article
}

available for both cell entities for decades. At second sight, however, major challenges prevail to reliably define characteristics and properties shared by MSCs derived from various donors and from different species. Besides phenotypic features obviously pertinent to species (e.g. mouse vs. human; see later), the heterogeneity of MSC preparations in vitro as well as the heterogeneous distribution of stromal cells in the bone marrow (BM) in vivo may be regarded as major impediments that significantly slow down progress in basic and translational MSC research as well as in development of MSC therapies.

Many published studies have described significant heterogeneity of cultured MSC preparations [5, 6]. These studies have identified the sources of such heterogeneity, amongst which the most pertinent are: culture's in-vitro 'age' [7-9]; cell seeding densities; media and other growth conditions, which may favour the expansion of only certain MSC subsets [10-12]; and, finally, the donor's age and possibly gender $[6,13,14]$. In terms of MSC heterogeneity in vivo, it has now become clear that the cells' tissue and anatomical residence is most important, particularly in terms of MSC differentiation capacity [15-19]. But even in the same tissue, such as $\mathrm{BM}$, is there a biological and physiological basis for the existence of different MSC subsets?

This review will first focus on the in-vivo markers of BM-MSCs in human and mouse species, highlighting common and potentially functionally relevant receptor molecules. The article will then discuss developmental and topographical heterogeneity of MSCs in the BM and the importance of considering donor's age, gender and health status when studying in-vivo MSC functions in humans. This knowledge could inform novel strategies for prospective isolation of MSCs from their native environments in other tissues. With a better understanding of physiological MSC responses in vivo and their pathological characteristics in diseases such as osteoarthritis 
(OA) and osteoporosis (OP), MSCs could become future targets for therapeutic interventions.

\section{Surface markers for prospective isolation of BM-MSCs}

The BM was the first tissue from which MSCs were isolated and comprehensively investigated [20, 21]. This compartment is also the prime residence location for another adult stem/progenitor cell; that is, the HSC [22]. The BM is a highly heterogeneous tissue that, in addition to MSCs and HSCs, is composed of their progeny, including fully differentiated cells such as fat cells or plasma cells, as well as of endothelial cells and other non-haematopoietic elements such as nerve endings [23]. Furthermore, BM does not exist in isolation and is intimately connected with surrounding bone. Endosteal (inner bone) surfaces, which are in direct contact with the $\mathrm{BM}$, are covered with 'lining' cells that contain MSCs [24], their short-lived (osteoblasts) [25] and long-lived progeny [26] as well as most immature, quiescent HSCs [27]. Whilst in the past the search for BM-MSCs was limited to BM aspirates, more recent findings clearly showed that not all MSCs are obtained by aspiration [24, 28] and that enzymatic digestion of bone is definitely needed to recover additional MSCs from the bone-lining location [28-31].

In cell therapy and tissue engineering communities, MSC isolation commonly implies the production of plastic adherent cultures starting from minimally processed BM aspirates or tissue digests [3]. This method represents a retrospective way of isolating and expanding cultureinitiating MSCs whereby contaminating non-MSCs are lost owing to incompatible culture conditions, whereas MSCs are amplified (culture-based selection). In contrast, prospective MSC isolation requires having a candidate marker or markers to purify putative MSC subpopulation(s), followed by their in-vitro expansion and further functional tests such as multipotentiality, immunomodulation or secretion of trophic factors [3, 6, 31, 32] (markerbased selection). Up to now, in-vivo MSC markers suitable for prospective BM-MSC isolation were discovered either by screening of available hybridomas [33-35], from topographical 'clues' on histological sections, as was the case for CD271 [36], or from large gene array datasets comparing cultured MSCs with negative control skin fibroblasts or hematopoietic lineage cells [19, 37]. Naturally, markers of cultured MSCs, such as CD73, CD105 and CD90, have also been tested in both human and mouse species, and showed various degrees of success as single markers [3, 31, 38-42] (Table 1). At this point, it is important to note that the role of these various surface markers in MSC physiology in vivo remains largely unknown (Table 1). In fact, the best 'isolation' markers could be those which have a minimal role in MSC
Table 1 Markers and potential functions of native BM-MSCs

\begin{tabular}{|c|c|c|c|}
\hline $\begin{array}{l}\text { In-vivo MSC } \\
\text { marker }\end{array}$ & $\begin{array}{l}\text { Potential function on } \\
\text { MSCs }\end{array}$ & $\begin{array}{l}\text { Host/ } \\
\text { model }\end{array}$ & References \\
\hline \multirow[t]{2}{*}{$\overline{C D} 271$} & Osteogenesis & $\begin{array}{l}\text { Human, } \\
\text { murine } \\
\text { cell line }\end{array}$ & {$[96]$} \\
\hline & $\begin{array}{l}\text { Interactions with other } \\
\text { BM cells }\end{array}$ & Human & {$[51,97]$} \\
\hline $\begin{array}{l}\text { MSCA-1/Stro-3/ } \\
\text { non-specific } \\
\text { alkaline } \\
\text { phosphatase }\end{array}$ & $\begin{array}{l}\text { Osteogenesis/ } \\
\text { mineralization }\end{array}$ & Human & {$[34,98]$} \\
\hline Stro-1 & Migration/homing & Human & [99] \\
\hline CD146 & $\begin{array}{l}\text { Related to MSC } \\
\text { topography, } \\
\text { interaction with other } \\
\text { BM cells }\end{array}$ & Human & {$[24,50,54,100]$} \\
\hline \multirow[t]{2}{*}{$\begin{array}{l}\text { Leptin R } \\
\text { (CD295) }\end{array}$} & $\begin{array}{l}\text { Controlling bone-fat } \\
\text { balance }\end{array}$ & Mouse & {$[60]$} \\
\hline & Age-related & Human & {$[64]$} \\
\hline \multirow[t]{3}{*}{$\begin{array}{l}\text { PDGFRa } \\
\text { (CD140a) }\end{array}$} & Related to immaturity & $\begin{array}{l}\text { Mouse/ } \\
\text { human }\end{array}$ & {$[48] /[65]$} \\
\hline & Support HSCs & $\begin{array}{l}\text { Mouse/ } \\
\text { human }\end{array}$ & [30] \\
\hline & $\begin{array}{l}\text { Early adipogenic } \\
\text { commitment }\end{array}$ & $\begin{array}{l}\text { Mouse/ } \\
\text { human }\end{array}$ & [101] \\
\hline $\begin{array}{l}\text { PDGFR } \beta \\
\text { (CD140b) }\end{array}$ & Proliferation & Human & {$[61]$} \\
\hline CD49a & $\begin{array}{l}\text { Receptor for collagen } \\
\text { and laminin }\end{array}$ & Human & {$[39,102,103]$} \\
\hline \multirow[t]{2}{*}{ CD106 } & Migration & Human & {$[50,51]$} \\
\hline & $\begin{array}{l}\text { Interaction with other } \\
\text { BM cells }\end{array}$ & & [51] \\
\hline CD51 & Interaction with $\mathrm{HSCS}$ & $\begin{array}{l}\text { Mouse/ } \\
\text { human }\end{array}$ & [30] \\
\hline CD200 & Immunoregulation & Human & [104] \\
\hline \multirow[t]{2}{*}{ CD90 } & $\begin{array}{l}\text { Interactions with other } \\
\text { BM cells }\end{array}$ & Human & {$[39]$} \\
\hline & & Mouse & [51] \\
\hline
\end{tabular}

BM bone marrow, HSC hematopoietic stem cell, MSC mesenchymal stem/ stromal cell, MSCA-1 mesenchymal stem cell antigen-1, PDGFR platelet-derived growth factor receptor

functionality so that the process of MSC isolation itself has a minimal bearing on possible marker-mediated signal transduction and gene expression in isolated MSCs.

\section{Classes of BM-MSC surface markers based on their potential functions}

In BM aspirates, in flushed contents of cortical bones or, to a lesser extent, in cancellous bone tissue digests, MSCs represent a minority amongst other cell entities [21, 30, 31, 43, 44]. Therefore, so-called 'negative' markers are commonly used as the first 'pre-enrichment' step in order 
to enrich MSCs to a certain degree of purity (>1\%) required for subsequent downstream investigations $[24,30]$. In particular, the CD45 antigen has been the most commonly used negative selection marker in both human studies [24, 30, 45, 46] and mouse studies [30, 47, 48].

In humans, CD271 and mesenchymal stem cell antigen1 (MSCA-1; tissue non-specific alkaline phosphatase) have been proposed as specific positive markers for BM-MSCs [34, 40, 49-51]. Stro-1, the first-discovered marker of human BM-MSCs, is cross-reactive with erythroblasts [52] and hence needs to be used in combination with other positive markers [53-55]. Various integrin molecules (CD49a, CD106 and CD146) have been independently validated as expressed on human in-vivo BM-MSCs in numerous original and more recent studies (Table 1). Importantly, the MSC integrin expression pattern seems to be dependent on MSC topographical location; for example, CD146 is expressed on MSCs located perivascularly, but it is absent on MSCs resident in the bone-lining location [24]. Integrins are involved in cell-to-cell and cell-tomatrix interactions [56]. Therefore, a future discovery of more comprehensive patterns of integrin expression on MSCs in different BM niches in the BM could shed more light on their functions and behaviours in vivo. A similar study pertaining to chemokine receptors on BM-MSCs [57-59] could be very valuable in terms of our current understanding of their migration and their homing properties, particularly in relation to fracture repair and bone remodelling processes.

In the mouse system, integrin $\alpha \mathrm{V}$ (CD51) [30] has attracted increased attention as being specific for BMMSCs; however, more recent findings have highlighted the value of growth factor receptors such as plateletderived growth factor receptor (PDGFR) alpha (CD140a) $[30,48]$ and leptin receptor (CD295) [60] for the selection of mouse MSCs. These molecules, as well as PDGFR $\beta$ (CD140b), have been contemporarily shown to be expressed on human BM-MSCs [60-62]; these surface molecules, in our opinion, therefore represent the first set of common markers applicable to both mouse and human species.

Human Stro-1-positive or CD271-positive BM-MSCs additionally express a large number of other growth factor receptors; for example, epidermal growth factor receptor (EGFR) and insulin-like growth factor receptor (IGFR). Notably, some of these molecules have a clear proliferation-promoting effect on MSCs [63]. In fact, the expression levels of these growth factor receptors on MSCs might indicate the level of their 'readiness' to respond to respective growth factor signals [62]. Yet only limited data exist for bone morphogenetic protein (BMP)/transforming growth factor (TGF) beta [64] and Wnt pathway receptor expression [61, 64, 65] on human or mouse MSCs in vivo; studies on these targets are clearly merited given the important role of these pathways in the maintenance and repair of bone [66].

PDGFR $\alpha$ (CD140a), in combination with CD271, has been most recently proposed as a valuable discriminatory marker combination for highly enriched human BM-MSCs, but the data remain controversial. A recent study by Pinho et al. [30] showed that MSCs in fetal human BM feature expression of CD271 plus CD140a. On the other hand, Li et al. [65] recently demonstrated that in adult human BM true highly clonogenic MSCs express CD271 but not CD140a. The authors suggested that CD140a may be developmentally regulated [65], a feature also observed in relation to CD146 expression in fetal, paediatric and adult human BM [67]. In addition to being regulated developmentally, in vivo MSC receptors could possibly be regulated physiologically. For example, our recent study using a cohort of fracture patients has shown that CD140a and CD140b expression on their BM CD271 $1^{+}$MSCs was changeable and directly correlated with the levels of PDGFs (as well as platelet levels) in patients' blood [62]. This observation suggests that MSCs at a site remote to injury might react to systemically driven changes in corresponding signalling molecules. Based on these considerations it might be reasonable to suggest that cytokine and growth factor receptors on MSCs may not be the most valuable tools for MSC isolation because their levels could be developmentally and physiologically controlled. Conversely, they may be very useful for the study of MSC behaviour in vivo, especially with respect to donor age, gender and physiological/disease status.

Furthermore, it is likely that standard (but not yet fully controlled) conditions for growing MSCs in fetal calf serum, autologous serum or with the addition of platelet lysates could in fact select for only those MSCs that have a corresponding set of growth factor receptors and correspondingly 'de-select' for receptor-negative cells. For example, culturing MSCs in media containing platelet lysates, rich in human PDGF-BB, could 'select' (i.e. induce enhanced proliferation) of MSCs that have high levels of CD140b receptors and de-select for CD140b-negative MSCs. Further causes for apparent differences in the phenotypes between in vivo and cultured MSCs have been elaborated in other previous publications $[45,61,68,69]$.

\section{BM-MSC heterogeneity: topography, age, gender and disease}

As alluded to earlier, cell-to-cell and batch-to-batch heterogeneity of cultured MSCs can in some way reflect the heterogeneity of in vivo MSC populations. MSCs located perivascularly may have a markedly different set of functions compared with bone-lining MSCs. In the bone-lining compartment itself, MSCs are mixed together with their progeny: active osteoblasts [25], which 
exist only transiently in bone remodelling areas, and quiescent osteoblast descendants predominant in nonremodelling areas [26]. Specific surface markers for these two types of mature MSC-lineage cells have not so far been described in humans, despite some data on their differing transcriptional signatures in the mouse [70]. Stripping off all lining cells from the bone surface with the use of enzyme, as is performed currently $[28,29,51]$, is bound to result in mixed mesenchymal-lineage populations that differ in their maturity, which subsequently contributes to cultured MSC heterogeneity.

Age plays a profound role in shaping our skeleton. BM-MSCs are involved in bone remodelling processes directly (as progenitors of osteoblasts) and indirectly (via osteoblast control of osteoclast activation). It can therefore be expected that in-vivo MSC ageing (either in relation to their numbers, function or both) can have a direct bearing on bone physiology in aged adults. Several studies have investigated whether and how MSCs may age in vivo; for example, as a result of telomere shortening processes $[8,29]$ or via changes to the transcription of Wnt pathway receptor genes [64]. It is important to note that extracellular matrix produced by aged MSCs may further contribute to their ageing [71], suggesting an autocrine mechanism of regulation.

Age-related diseases such as OA and OP are associated with marked changes in bone strength and architecture, and are suggested to involve a defect (or altered function) in patients' BM-MSCs [72-77]. Owing to the scarcity of healthy human material (BM and bone), it is not surprising that many studies exploring human BM-MSC biology in vivo utilize OA femoral heads [51,78]. Nevertheless, the effect of disease on these MSCs should not be overlooked. As reported recently using mouse models of OA, the disease process itself is associated with increased subchondral bone MSC numbers and alterations in their intracellular signalling cascades leading to aberrant bone formation and angiogenesis for OA progression [73]. This process may be even more pertinent in the case of OP, in which alterations in MSC numbers and their responsiveness to leptin or to BMPs have been documented [75-77]. The study of growth factor and hormone receptor expression on OP-MSCs could lead to the discovery of novel compounds capable of switching the balance from bone destruction and in favour of bone formation in OP.

Several reports have indicated some gender-related differences in BM-MSCs from humans $[6,79]$ and other species $[14,80,81]$. Could these also be related to gender differences between MSCs in vivo? The data collected from the Leeds laboratory over the years indicate no significant difference in MSC numbers per millilitre of BM aspirate between age-matched males and females, regardless of whether BM samples were first processed for mononuclear cell isolation or used directly. Interestingly, Seeback et al. [79] documented significantly different BM-MSC responses to skeletal injury between males and females. Caution should be taken when interpreting $\mathrm{BM}$ aspirate data, however, because the quality of aspirates in terms of their total MSC numbers is considerably dependent on the surgical aspiration technique and dilution with blood [44, 82, 83], which is significantly variable not only between different institutions but also between different surgeons.

We have reported recently that BM-MSCs from male and female donors express androgen receptor [6], but their responsiveness to sex hormones in general remains underexplored. This knowledge could be potentially exploitable therapeutically; for example, by uncovering sex hormone sensitivity and downstream signalling cascades in BM-MSCs in women with postmenopausal OP.

\section{MSC heterogeneity: different developmental origins}

Human skull and neck bones are well known to be neural-crest derived whereas the remainder of the skeleton is mesoderm derived [84, 85]. Transcriptional differences in MSCs grown from skull and mesoderm-derived bones have been documented previously [15]. Nevertheless, there is no reason to suggest that MSCs in different bones are firmly fixed in their original locations and unable to migrate to other tissues. In fact, mouse BM-MSCs were found recently to represent a mixture of neural-crest and mesoderm-derived cells [86]. In the mouse, MSCs can easily circulate and home to injured tissues [87, 88], whereas in humans this ability seems to be lost, or at least impaired, at birth. MSCs can be readily found in fetal circulation in humans [89], but these cells have been detected only at exceptionally low numbers in adult human peripheral blood, even after a significant physiological insult $[62,88,90,91]$. The loss of MSC ability to circulate in the blood of humans post-birth could be related to differential expression of some developmentally regulated molecules on their surface (e.g. CD146, CD140a or others), as mentioned in "Classes of BM-MSC surface markers based on their potential functions" above.

Despite the observation that endogenous (not transplanted) human MSCs are unable to be distributed across long distances via the systemic circulation, their shortdistance migration between the adjacent tissues remains plausible. MSCs express a broad portfolio of chemokine receptors enabling them to migrate along the chemokine gradients or, in contrast, to be retained in their original places [58]. Based on these considerations, it is possible to suggest that MSCs in any given tissue, including the BM, may represent a mixture of locally derived cells as well as 'migrants' from the neighbouring tissues. 


\section{Conclusion}

The BM is the tissue in which MSCs were discovered originally and remains the best-studied tissue source of MSCs. Even a quick look at the current state of the art in in-vivo MSCs in human and mouse BM suggests that a single marker specific for all MSC 'shades and colours' is unlikely to be found soon. In-vivo BM-MSC heterogeneity could be explored in the future using different approaches. For example, using a combination of immunohistochemical and cell sorting techniques, separate BM-MSC subsets can be isolated based on their topographical residence. Specific molecular marks indicative of MSC embryonic tissue origins, such as HOX and other 'positional identity' genes [17, 92], could be used next to shed a light on migratory routes of different classes of MSCs during development and in early childhood. Equally, their differential survival or impaired function during ageing could help to better understand the role of BM-MSCs in the development of age-related bone diseases such as OP.

When BM-MSCs from different species are compared, several considerations should be taken into account, the prime one being the type of host bone used to extract the MSCs. Most BM-MSC investigations in mice have been performed using flushed contents of cortical bones, whereas human BM-MSC research has primarily explored MSCs resident in marrow spaces inside certain cancellous bones (most often, the iliac crest). Only limited data yet exist on the gene expression profiles of uncultured BM-MSCs from donor-matched cancellous and cortical bones in humans [93]. Even if the same type of bone (e.g. femur) is used in human and mouse research, it is important to consider the effects of different mechanical loads experienced by bipeds as opposed to quadrupeds; the mechanical effects driving bone remodelling and hence the physiological demand on femoral MSCs in bipeds are likely to be very unique. Still, it is very encouraging to observe some emerging commonality in CD140 and CD295 receptor expression on BM-MSCs from both mouse and human species (Table 1). These common receptor molecules may be indicative of key BM-MSC functions distinct from their mechanically driven bone-remodelling activity; for example, of their control of the bone-fat balance in the marrow or of their support to HSCs.

Finally, to what extent can BM-MSC knowledge be extrapolated to MSCs in other issues? In our view, the best 'toolkit' to isolate the bulk of tissue-resident MSCs may not overlap with BM-MSCs [18], and this needs to be looked into on a tissue-to-tissue basis. Potential back and forth 'passaging' of MSCs between the neighbouring tissues should be also considered, which could explain, at least in part, the observed heterogeneity of MSCs in the respective tissue.
Most MSCs are lodged within the stroma of solid tissues and organs, making it very difficult to study their self-renewal and their participation in physiological tissue renewal in a classical manner similar to HSCs or even BM-MSCs [94]. In this respect, gene-tracing experiments in mouse models are of a paramount importance in order to understand normal MSC behaviour in tissues and organs and their responses to injury or disease [95]. With further appreciation of probable differences in MSC biology between 'mice and men', this future knowledge is likely to generate new ideas and bring forward new treatments for many human diseases.

Note: This article is part of a thematic series 'Mesenchymal

Stem/Stromal Cells-An update'. Other articles in this series can

be found at http://www.biomedcentral.com/series/mesenchymal

\section{Abbreviations}

BM: Bone marrow; BMP: Bone morphogenetic protein; EGFR: Epidermal growth factor receptor; HSC: Hematopoietic stem cell; IGFR: Insulin-like growth factor receptor; MSC: Mesenchymal stem/stromal cell; OA: Osteoarthritis; OP: Osteoporosis; PDGFR: Platelet-derived growth factor receptor; TGF: Transforming growth factor.

\section{Competing interests}

The authors declare that they have no competing interests.

\section{Acknowledgements}

EJ's research is funded through WELMEC, a Centre of Excellence in Medical Engineering funded by the Wellcome Trust and the Engineering and Physical Sciences Research Council, under grant number WT 088908/Z/09/Z and the National Institute of Health Research-funded Leeds Biomedical Research Unit. RS's research is funded through the Research Fund of the German Red Cross Blood Donor Service.

\section{Author details}

${ }^{1}$ Leeds Institute of Rheumatic and Musculoskeletal Medicine, Leeds University, Room 5.24 Clinical Sciences Building, St James's University Hospital, Leeds LS9 7TF, UK. ${ }^{2}$ Institute for Transfusion Medicine and Immunohaematology, German Red Cross Blood Donor Service, Baden-Württemberg-Hessen gGmbH, Johann-Wolfgang-Goethe University Hospital, Sandhofstrasse 1, D-60528 Frankfurt am Main, Germany.

Published online: 18 August 2015

\section{References}

1. Bianco P, Cao X, Frenette PS, Mao JJ, Robey PG, Simmons PJ, et al. The meaning, the sense and the significance: translating the science of mesenchymal stem cells into medicine. Nat Med. 2013;19:35-42.

2. Pittenger MF. MSCs: science and trials. Nat Med. 2013;19:811.

3. Galderisi U, Giordano A. The gap between the physiological and therapeutic roles of mesenchymal stem cells. Med Res Rev. 2014;34:1100-26.

4. Gerson SL. Mesenchymal stem cells: no longer second class marrow citizens. Nat Med. 1999;5:262-4.

5. Schellenberg A, Stiehl T, Horn P, Joussen S, Pallua N, Ho AD, et al. Population dynamics of mesenchymal stromal cells during culture expansion. Cytotherapy. 2012;14:401-11.

6. Siegel G, Kluba T, Hermanutz-Klein U, Bieback K, Northoff H, Schaefer R. Phenotype, donor age and gender affect function of human bone marrow-derived mesenchymal stromal cells. BMC Med. 2013;11:146.

7. DiGirolamo CM, Stokes D, Colter D, Phinney DG, Class R, Prockop DJ. Propagation and senescence of human marrow stromal cells in culture: a 
simple colony-forming assay identifies samples with the greatest potential to propagate and differentiate. Br J Haematol. 1999;107:275-81.

8. Baxter MA, Wynn RF, Jowitt SN, Wraith JE, Fairbairn L, Bellantuono I. Study of telomere length reveals rapid aging of human marrow stromal cells following in vitro expansion. Stem Cells. 2004;22:675-82.

9. Wagner W, Horn P, Castoldi M, Diehlmann A, Bork S, Saffrich R, et al. Replicative senescence of mesenchymal stem cells: a continuous and organized process. PLoS One. 2008;3, e2213.

10. Colter DC, Sekiya I, Prockop DJ. Identification of a subpopulation of rapidly self-renewing and multipotential adult stem cells in colonies of human marrow stromal cells. Proc Natl Acad Sci U S A. 2001;98:7841-5.

11. D'Ippolito G, Diabira S, Howard GA, Menei P, Roos BA, Schiller PC. Marrow-isolated adult multilineage inducible (MIAMI) cells, a unique population of postnatal young and old human cells with extensive expansion and differentiation potential. J Cell Sci. 2004;117:2971-81.

12. Di Maggio N, Mehrkens A, Papadimitropoulos A, Schaeren S, Heberer M, Banfi A, et al. Fibroblast growth factor-2 maintains a niche-dependent population of self-renewing highly potent non-adherent mesenchymal progenitors through FGFR2c. Stem Cells. 2012;30:1455-64.

13. Sethe S, Scutt A, Stolzing A. Aging of mesenchymal stem cells. Ageing Res Rev. 2006:5:91-116.

14. Katsara O, Mahaira LG, lliopoulou EG, Moustaki A, Antsaklis A, Loutradis D, et al. Effects of donor age, gender, and in vitro cellular aging on the phenotypic, functional, and molecular characteristics of mouse bone marrow-derived mesenchymal stem cells. Stem Cells Dev. 2011;20:1550-62.

15. Akintoye SO, Lam T, Shi ST, Brahim J, Collins MT, Robey PG. Skeletal sitespecific characterization of orofacial and iliac crest human bone marrow stromal cells in same individuals. Bone. 2006;38:758-68.

16. Risbud MV, Shapiro IM, Guttapalli A, Di Martino A, Danielson KG, Beiner JM, et al. Osteogenic potential of adult human stem cells of the lumbar vertebral body and the iliac crest. Spine (Phila Pa 1976). 2006;31:83-9.

17. Ackema KB, Charite J. Mesenchymal stem cells from different organs are characterized by distinct topographic Hox codes. Stem Cells Dev. 2008;17:979-91.

18. Watson JT, Foo T, Wu J, Moed BR, Thorpe M, Schon L, et al. CD271 as a marker for mesenchymal stem cells in bone marrow versus umbilical cord blood. Cells Tissues Organs. 2013;197:496-504.

19. Igarashi A, Segoshi K, Sakai Y, Pan H, Kanawa M, Higashi $Y$, et al. Selection of common markers for bone marrow stromal cells from various bones using real-time RT-PCR: effects of passage number and donor age. Tissue Eng. 2007;13:2405-17

20. Friedenstein AJ, Chailakhyan RK, Gerasimov UV. Bone-marrow osteogenic stem-cells - in vitro cultivation and transplantation in diffusion-chambers. Cell Tissue Kinetics. 1987;20:263-72.

21. Pittenger MF, Mackay AM, Beck SC, Jaiswal RK, Douglas R, Mosca JD, et al. Multilineage potential of adult human mesenchymal stem cells. Science. 1999;284:143-7.

22. Appelbaum FR. Hematopoietic-cell transplantation at 50. N Engl J Med. 2007;357:1472-5.

23. Mendez-Ferrer S, Lucas D, Battista M, Frenette PS. Haematopoietic stem cell release is regulated by circadian oscillations. Nature. 2008;452:442-4.

24. Tormin A, Li O, Brune JC, Walsh S, Schütz B, Ehinger M, et al. CD146 expression on primary non-hematopoietic bone marrow stem cells correlates to in situ localization. Blood. 2011;117:5067-77.

25. Manolagas SC, Parfitt AM. For whom the bell tolls: distress signals from long-lived osteocytes and the pathogenesis of metabolic bone diseases. Bone. 2013;54:272-8

26. Hauge EM, Qvesel D, Eriksen EF, Mosekilde L, Melsen F. Cancellous bone remodeling occurs in specialized compartments lined by cells expressing osteoblastic markers. J Bone Miner Res. 2001;16:1575-82.

27. Asada N, Katayama Y. Regulation of hematopoiesis in endosteal microenvironments. Int J Hematol. 2014;99:679-84.

28. Sakaguchi Y, Sekiya I, Yagishita K, Ichinose S, Shinomiya K, Muneta T. Suspended cells from trabecular bone by collagenase digestion become virtually identical to mesenchymal stem cells obtained from marrow aspirates. Blood. 2004;104:2728-35.

29. Jones E, English A, Churchman SM, Kouroupis D, Boxall SA, Kinsey S, et al. Large-scale extraction and characterization of CD271+ multipotential stromal cells from trabecular bone in health and osteoarthritis: implications for bone regeneration strategies based on uncultured or minimally cultured multipotential stromal cells. Arthritis Rheum. 2010;62:1944-54.
30. Pinho S, Lacombe J, Hanoun M, Mizoguchi T, Bruns I, Kunisaki Y, et al. PDGFR alpha and CD51 mark human Nestin(+) sphere-forming mesenchymal stem cells capable of hematopoietic progenitor cell expansion. J Exp Med. 2013;210:1351-67.

31. Mabuchi Y, Houlihan DD, Akazawa C, Okano H, Matsuzaki Y. Prospective isolation of murine and human bone marrow mesenchymal stem cells based on surface markers. Stem Cells Int. 2013;2013:507301.

32. Harichandan A, Buehring $\mathrm{H}$-J. Prospective isolation of human MSC. Best Practice Res Clin Haematol. 2011;24:25-36.

33. Buhring $\mathrm{H}-J$, Battula VL, Treml S, Schewe B, Kanz L, Vogel W. Novel markers for the prospective isolation of human MSC. Ann N Y Acad Sci. 2007;1106:262-71.

34. Sobiesiak M, Sivasubramaniyan K, Hermann C, Tan C, Oergel M, Treml S, et al. The mesenchymal stem cell antigen MSCA-1 is identical to tissue non-specific alkaline phosphatase. Stem Cells Dev. 2010;19:669-77.

35. Sivasubramaniyan K, Harichandan A, Schumann S, Sobiesiak M, Lengerke C, Maurer A, et al. Prospective isolation of mesenchymal stem cells from human bone marrow using novel antibodies directed against sushi domain containing 2. Stem Cells Dev. 2013;22:1944-54.

36. Cattoretti G, Schiro R, Orazi A, Soligo D, Colombo MP. Bone-marrow stroma in humans - anti-nerve growth-factor receptor antibodies selectively stain reticular cells in vivo and in vitro. Blood. 1993;81:1726-38.

37. Halfon S, Abramov N, Grinblat B, Ginis I. Markers distinguishing mesenchymal stem cells from fibroblasts are downregulated with passaging. Stem Cells Dev. 2011;20:53-66.

38. Aslan H, Zilberman Y, Kandel L, Liebergall M, Oskouian RJ, Gazit D, et al. Osteogenic differentiation of noncultured immunoisolated bone marrow-derived CD105+ cells. Stem Cells. 2006;24:1728-37.

39. Boiret N, Rapatel C, Veyrat-Masson R, Guillouard L, Guerin JJ, Pigeon P, et al. Characterization of nonexpanded mesenchymal progenitor cells from normal adult human bone marrow. Exp Hematol. 2005;33:219-25.

40. Boxall SA, Jones E. Markers for characterization of bone marrow multipotential stromal cells. Stem Cells Int. 2012;2012:975871.

41. Chan CKF, Lindau P, Jiang W, Chen JY, Zhang LF, Chen C-C, et al. Clonal precursor of bone, cartilage, and hematopoietic niche stromal cells. Proc Natl Acad Sci U S A. 2013;110:12643-8.

42. Bara JJ, Richards RG, Alini M, Stoddart MJ. Concise review: Bone marrow-derived mesenchymal stem cells change phenotype following in vitro culture: implications for basic research and the clinic. Stem Cells. 2014;32:1713-23.

43. Veyrat-Masson R, Boiret-Dupre N, Rapatel C, Descamps S, Guillouard L, Guerin J-J, et al. Mesenchymal content of fresh bone marrow: a proposed quality control method for cell therapy. Br J Haematol. 2007;139:312-20.

44. Cuthbert R, Boxall SA, Tan HB, Giannoudis PV, McGonagle D, Jones E. Single-platform quality control assay to quantify multipotential stromal cells in bone marrow aspirates prior to bulk manufacture or direct therapeutic use. Cytotherapy. 2012;14:431-40.

45. Qian H, Le Blanc K, Sigvardsson M. Primary mesenchymal stem and progenitor cells from bone marrow lack expression of CD44. J Biol Chem. 2012;287:25795-807.

46. Hall SRR, Jiang Y, Leary E, Yavanian G, Eminli S, O'Neill DW, et al. Identification and isolation of small CD44-negative mesenchymal stem/ progenitor cells from human bone marrow using elutriation and polychromatic flow cytometry. Stem Cells Trans Med. 2013;2:567-78,

47. Baddoo M, Hill K, Wilkinson R, Gaupp D, Hughes C, Kopen GC, et al. Characterization of mesenchymal stem cells isolated from murine bone marrow by negative selection. J Cell Biochem. 2003;89:1235-49.

48. Morikawa S, Mabuchi Y, Kubota Y, Nagai Y, Niibe K, Hiratsu E, et al. Prospective identification, isolation, and systemic transplantation of multipotent mesenchymal stem cells in murine bone marrow. J Exp Med. 2009;206:2483-96.

49. Jones EA, English A, Kinsey SE, Straszynski L, Emery P, Ponchel F, et al. Optimization of a flow cytometry-based protocol for detection and phenotypic characterization of multipotent mesenchymal stromal cells from human bone marrow. Cytom B Clin Cytom. 2006;70:391-9.

50. Battula VL, Treml S, Bareiss PM, Gieseke F, Roelofs H, de Zwart P, et al. Isolation of functionally distinct mesenchymal stem cell subsets using antibodies against CD56, CD271, and mesenchymal stem cell antigen-1. Haematologica. 2009;94:173-84.

51. Mabuchi Y, Morikawa S, Harada S, Niibe K, Suzuki S, Renault-Mihara F, et al. LNGFR(+)THY-1(+)VCAM-1(hi+) cells reveal functionally distinct subpopulations in mesenchymal stem cells. Stem Cell Reports. 2013;1:152-65. 
52. Simmons PJ, Torokstorb B. Identification of stromal cell precursors in human bone-marrow by a novel monoclonal-antibody, Stro-1. Blood. 1991;78:55-62.

53. Gronthos S, Zannettino ACW, Hay SJ, Shi ST, Graves SE, Kortesidis A, et al. Molecular and cellular characterisation of highly purified stromal stem cells derived from human bone marrow. J Cell Sci. 2003;116:1827-35.

54. Shi S, Gronthos S. Perivascular niche of postnatal mesenchymal stem cells in human bone marrow and dental pulp. J Bone Miner Res. 2003;18:696-704.

55. Gothard D, Greenhough J, Ralph E, Oreffo RO. Prospective isolation of human bone marrow stromal cell subsets: a comparative study between Stro-1-, CD146- and CD105-enriched populations. J Tissue Eng. 2014;5:1-17.

56. Goessler UR, Bugert P, Bieback K, Stern-Straeter J, Bran G, Hoermann K, et al. Integrin expression in stem cells from bone marrow and adipose tissue during chondrogenic differentiation. Int J Mol Med. 2008;21:271-9.

57. Wynn RF, Hart CA, Corradi-Perini C, O'Neill L, Evans CA, Wraith JE, et al. A small proportion of mesenchymal stem cells strongly expresses functionally active CXCR4 receptor capable of promoting migration to bone marrow. Blood. 2004;104:2643-5.

58. Honczarenko M, Le Y, Swierkowski M, Ghiran I, Glodek AM, Silberstein LE. Human bone marrow stromal cells express a distinct set of biologically functional chemokine receptors. Stem Cells. 2006;24:1030-41.

59. Ringe J, Strassburg S, Neumann K, Endres M, Notter M, Burmester G-R, et al. Towards in situ tissue repair: human mesenchymal stem cells express chemokine receptors CXCR1, CXCR2 and CCR2, and migrate upon stimulation with CXCL8 but not CCL2. J Cell Biochem. 2007;101:135-46.

60. Zhou BO, Yue R, Murphy MM, Peyer JG, Morrison SJ. Leptin-receptor-expressing mesenchymal stromal cells represent the main source of bone formed by adult bone marrow. Cell Stem Cell. 2014;15:154-68.

61. Buhring HJ, Treml S, Cerabona F, de Zwart P, Kanz L, Sobiesiak M. Phenotypic characterization of distinct human bone marrow-derived MSC subsets. Ann N Y Acad Sci. 2009;1176:124-34.

62. Tan HB, Giannoudis PV, Boxall SA, McGonagle D, Jones E. The systemic influence of platelet-derived growth factors on bone marrow mesenchymal stem cells in fracture patients. BMC Med. 2015;13:6.

63. Gronthos S, Simmons PJ. The growth-factor requirements of Stro-1-positive human bone-marrow stromal precursors under serum-deprived conditions in-vitro. Blood. 1995:85:929-40.

64. Churchman SM, Ponchel F, Boxall SA, Cuthbert R, Kouroupis D, Roshdy T, et al. Transcriptional profile of native CD271+ multipotential stromal cells: evidence for multiple fates, with prominent osteogenic and Wnt pathway signaling activity. Arthritis Rheum. 2012;64:2632-43.

65. Li H, Ghazanfari R, Zacharaki D, Ditzel N, Isern J, Ekblom M, et al. Low/ negative expression of PDGFR-alpha identifies the candidate primary mesenchymal stromal cells in adult human bone marrow. Stem Cell Reports. 2014;3:965-74.

66. Augello A, De Bari C. The regulation of differentiation in mesenchymal stem cells. Hum Gene Ther. 2010;21:1226-38.

67. Maijenburg MW, Kleijer M, Vermeul K, Mul EPJ, van Alphen FPJ, van der Schoot CE, et al. The composition of the mesenchymal stromal cell compartment in human bone marrow changes during development and aging. Haematologica. 2012;97:179-83.

68. Delorme B, Ringe J, Gallay N, Le Vern Y, Kerboeuf D, Jorgensen C, et al. Specific plasma membrane protein phenotype of culture-amplified and native human bone marrow mesenchymal stem cells. Blood. 2008;111:2631-5.

69. Jones E, Schäfer R. Biological differences between native and cultured mesenchymal stem cells: implications for therapies. Stem Cell Protocols. 2015;1235:105-20

70. Balduino A, Mello-Coelho V, Wang Z, Taichman RS, Krebsbach PH, Weeraratna AT, et al. Molecular signature and in vivo behavior of bone marrow endosteal and subendosteal stromal cell populations and their relevance to hematopoiesis. Exp Cell Res. 2012;318:2427-37.

71. Sun Y, Li W, Lu Z, Chen R, Ling J, Ran Q, et al. Rescuing replication and osteogenesis of aged mesenchymal stem cells by exposure to a young extracellular matrix. Faseb J. 2011;25:1474-85.

72. Murphy JM, Dixon K, Beck S, Fabian D, Feldman A, Barry F. Reduced chondrogenic and adipogenic activity of mesenchymal stem cells from patients with advanced osteoarthritis. Arthritis Rheum. 2002;46:704-13.

73. Zhen GH, Wen CY, Jia XF, Li Y, Crane JL, Mears SC, et al. Inhibition of TGFbeta signaling in mesenchymal stem cells of subchondral bone attenuates osteoarthritis. Nat Med. 2013;19:704-12.
74. Astudillo P, Rios S, Pastenes L, Pino AM, Rodriguez JP. Increased adipogenesis of osteoporotic human-mesenchymal stem cells (MSCs) is characterized by impaired leptin action. J Cell Biochem. 2008;103:1054-65.

75. Rodriguez JP, Garat S, Gajardo H, Pino AM, Seitz G. Abnormal osteogenesis in osteoporotic patients is reflected by altered mesenchymal stem cells dynamics. J Cell Biochem. 1999;75:414-23.

76. Rodriguez JP, Montecinos L, Rios S, Reyes P, Martinez J. Mesenchymal stem cells from osteoporotic patients produce a type I collagen-deficient extracellular matrix favoring adipogenic differentiation. J Cell Biochem. 2000;79:557-65.

77. Haasters F, Docheva D, Gassner C, Popov C, Boecker W, Mutschler W, et al. Mesenchymal stem cells from osteoporotic patients reveal reduced migration and invasion upon stimulation with BMP-2 or BMP-7. Biochem Biophys Res Commun. 2014;452:118-23.

78. Etheridge SL, Spencer GJ, Heath DJ, Genever PG. Expression profiling and functional analysis of Wnt signaling mechanisms in mesenchymal stem cells. Stem Cells. 2004;22:849-60.

79. Seebach C, Henrich D, Tewksbury R, Wilhelm K, Marzi I. Number and proliferative capacity of human mesenchymal stem cells are modulated positively in multiple trauma patients and negatively in atrophic nonunions. Calcif Tissue Int. 2007:80:294-300.

80. Strube P, Mehta M, Baerenwaldt A, Trippens J, Wilson CJ, Ode A, et al. Sex-specific compromised bone healing in female rats might be associated with a decrease in mesenchymal stem cell quantity. Bone. 2009;45:1065-72.

81. Bragdon B, Burns R, Baker AH, Belkina AC, Morgan EF, Denis GV, et al. Intrinsic sex-linked variations in osteogenic and adipogenic differentiation potential of bone marrow multipotent stromal cells. J Cell Physiol. 2015;230:296-307.

82. Muschler GF, Boehm C, Easley K. Aspiration to obtain osteoblast progenitor cells from human bone marrow: the influence of aspiration volume. J Bone Joint Surg Am. 1997;79A:1699-709.

83. Hernigou P, Homma Y, Lachaniette CHF, Poignard A, Allain J, Chevallier N, et al. Benefits of small volume and small syringe for bone marrow aspirations of mesenchymal stem cells. Int Orthopaed. 2013;37:2279-87.

84. Kobayashi T, Kronenberg HM. Overview of skeletal development. In: Hilton MJ, editor. Skeletal development and repair: methods and protocols, vol. 1130. Totowa: Humana Press; 2014. p. 3-12.

85. Munoz WA, Trainor PA. Neural crest cell evolution: how and when did a neural crest cell become a neural crest cell. Curr Topics Dev Biol. 2015;111:3-26.

86. Komada Y, Yamane T, Kadota D, Isono K, Takakura N, Hayashi S-I, et al. Origins and properties of dental, thymic, and bone marrow mesenchymal cells and their stem cells. PLoS One. 2012;7, e46436.

87. Granero-Molto F, Weis JA, Miga MI, Landis B, Myers TJ, O'Rear L, et al. Regenerative effects of transplanted mesenchymal stem cells in fracture healing. Stem Cells. 2009;27:1887-98.

88. Ito $\mathrm{H}$. Chemokines in mesenchymal stem cell therapy for bone repair: a novel concept of recruiting mesenchymal stem cells and the possible cell sources. Mod Rheumatol. 2011;21:113-21.

89. Campagnoli C, Roberts IAG, Kumar S, Bennett PR, Bellantuono I, Fisk NM. Identification of mesenchymal stem/progenitor cells in human first-trimester fetal blood, liver, and bone marrow. Blood. 2001;98:2396-402.

90. Kuznetsov SA, Mankani MH, Gronthos S, Satomura K, Bianco P, Robey PG. Circulating skeletal stem cells. J Cell Biol. 2001;153:1133-9.

91. Hoogduijn MJ, Verstegen MM, Engela AU, Korevaar SS, Roemeling-van Rhijn M, Merino A, et al. No evidence for circulating mesenchymal stem cells in patients with organ injury. Stem Cells Dev. 2014;23:2328-35.

92. Sagi B, Maraghechi P, Urban VS, Hegyi B, Szigeti A, Fajka-Boja R, et al. Positional identity of murine mesenchymal stem cells resident in different organs is determined in the postsegmentation mesoderm. Stem Cells Dev. 2012;21:814-28.

93. Churchman SM, Kouroupis D, Boxall SA, Roshdy T, Tan HB, McGonagle D, et al. Yield optimisation and molecular characterisation of uncultured CD271+ mesenchymal stem cells in the Reamer Irrigator Aspirator waste bag. Eur Cell Mater. 2013;26:252-62.

94. Sacchetti B, Funari A, Michienzi S, Di Cesare S, Piersanti S, Saggio I, et al. Self-renewing osteoprogenitors in bone marrow sinusoids can organize a hematopoietic microenvironment. Cell. 2007;131:324-36.

95. Kozhemyakina E, Zhang M, lonescu A, Ayturk UM, Ono N, Kobayashi A, et al. Identification of a Prg4-expressing articular cartilage progenitor cell population in mice. Arthritis Rheumatol. 2015;67:1261-73. 
96. Alexander D, Schafer F, Munz A, Friedrich B, Klein C, Hoffmann J, et al. LNGFR induction during osteogenesis of human jaw periosteum-derived cells. Cell Physiol Biochem. 2009;24:283-90

97. Rezaee F, Rellick SL, Piedimonte G, Akers SM, O'Leary HA, Martin K, et al. Neurotrophins regulate bone marrow stromal cell IL-6 expression through the MAPK pathway. Plos One. 2010;5, e9690.

98. Gronthos S, Fitter S, Diamond P, Simmons PJ, Itescu S, Zannettin ACW. A novel monoclonal antibody (STRO-3) identifies an isoform of tissue nonspecific alkaline phosphatase expressed by multipotent bone marrow stromal stem cells. Stem Cells Dev. 2007;16:953-63.

99. Bensidhoum M, Chapel A, Francois S, Demarquay C, Mazurier C, Fouillard L, et al. Homing of in vitro expanded Stro-1(-) or Stro-1(+) human mesenchymal stem cells into the NOD/SCID mouse and their role in supporting human CD34 cell engraftment. Blood. 2004;103:3313-9.

100. Sorrentino A, Ferracin M, Castelli G, Biffoni M, Tomaselli G, Baiocchi M, et al. Isolation and characterization of CD146(+) multipotent mesenchymal stromal cells. Exp Hematol. 2008;36:1035-46.

101. Rostovskaya M, Anastassiadis K. Differential expression of surface markers in mouse bone marrow mesenchymal stromal cell subpopulations with distinct lineage commitment. Plos One. 2012;7, e51221.

102. Stewart K, Monk P, Walsh S, Jefferiss CM, Letchford J, Beresford JN. STRO-1, HOP-26 (CD63), CD49a and SB-10 (CD166) as markers of primitive human marrow stromal cells and their more differentiated progeny: a comparative investigation in vitro. Cell Tissue Res. 2003;313:281-90.

103. Deschaseaux F, Gindraux F, Saadi R, Obert L, Chalmers D, Herve P. Direct selection of human bone marrow mesenchymal stem cells using an anti-CD49a antibody reveals their CD45(med, low) phenotype. Br J Haematol. 2003:122:506-17.

104. Najar M, Raicevic G, Jebbawi F, De Bruyn C, Meuleman N, Bron D, et al. Characterization and functionality of the CD200-CD200R system during mesenchymal stromal cell interactions with T-lymphocytes. Immunol Lett. 2012;146:50-6. 